\title{
ANALISIS PEMETAAN FUNGSI WAKTU PRODUKSI \\ PADA HOME INDUSTRI (COSH MOTOR) JASA PEMBUATAN ONDERDIL MOTOR DI PASURUAN
}

\author{
Siti Rochmaniyah \\ Department of Management FEB UMM \\ E-mail: vania.nia16@gmail.com
}

\begin{abstract}
The research objective was to overcome the problem of wastage of time in the production processed by planning the mapping function of time for workers and owners of home industry for the production processed to avoid waste of time and reduce the damage.The analytical tool used was a function mapping the basis for knowing which processes were causing wastage of time.The analysis shows the mapping function of time base production processed it can be seen, there were four processed were experiencing wastage of time that was controlling the processed, waiting for turning, waiting for staining, and warehouse, with two factors, namely the engine and human issues. Of the two factors, the problem may be known solution was to increase the machine and provide training to employees to avoid errors in the production processed. In addition to the mapping function target time in order to indicate whether the implemented solution had provided an increase in the production processed and the company's operations can be run effectively and efficiently.
\end{abstract}

Keywords: Spare Parts, Wasting Time, Mapping Functions Time, Machine.

\section{PENDAHULUAN}

Saat ini sektor perindustrian di seluruh dunia sangat berkembang pesat, begitu pula di Indonesia. Indonesia merupakan negara yang menjadikan sektor industri menjadi mata pencaharian sebagian besar penduduknya. Hal ini dibuktikan dari banyaknya industri-industri yang menggunakan teknologi yang cukup baik sehingga banyak sektor industri di Indonesia dapat menembus pasar asing. Agar dapat memenangkan persaingan tersebut maka dapat dengan menerapkan manajemen operasional efisien, dengan strategi proses. Pemilihan strategi proses dilakukan sebagai keputusan operasional.
Strategi proses memiliki dampak yang besar terhadap perencanaan kapasitas dalam produksi, peralatan-peralatan yang akan digunakan, desain sistem kerja, serta tata letak fasilitas yang ada pada suatu perusahaan. Salah satu alat yang dapat digunakan untuk menganalisis dan desain proses adalah metode pemetaan fungsi waktu.

Pemetaan fungsi waktu digunakan untuk mengidentifikasi dan menghilangkan pemborosan dalam hal langkah tambahan, pengulangan, dan keterlambatan yang tidak perlu terjadi dalam hal proses produksi agar mengurangi dan menutupi kerugian yang ada dalam sebuah perusahaan maupun industri. 
Saat ini perusahaan dituntut untuk lebih efisien dalam melakukan kegiatan produksinyap namun, permasalahan yang dihadapi oleh perusahaan terkadang adalah banyaknya kerusakan yang membutuhkan perbaikan ulang sehingga meningkatkan biaya produksi. Salah satunya contoh usaha yang berhubungan dengan permasalahan diatas home industry di daerah Persapen Pasuruan yang memproduksi berbagai accessories dan variasi motor. Home industry ini memiliki brand "Cosh Motor".

Cosh Motor ini dalam proses produksi menggunakan bahan ramah lingkungan yaitu daur ulang limbah alumunium, seng, dan besi sebagai bahan baku. Pemilik Cosh Motor menjalankan proses produksi berdasarkan pengalaman kerja tanpa mengetahui ilmu-ilmu yang sebenarnya digunakan secara keseluruhan. Sehingga dalam jumlah proses produksi yang tidak sedikit, home industry ini seringkali mengalami permasalahan salah satunya yaitu hasil produksi cacat sebelum di tangan konsumen sehingga terjadi perbaikan. Pada tabel 1 adalah beberapa data transaksi penjualan yang terdapat kerusakan produk ketika telah sampai ditangan konsumen.Dari penjelasan di atas dapat disimpulkan bahwa home industry tersebut membutuhkan penganalisisan menggunakan pemetaan fungsi waktu dalam menjalankan proses produksi. Analisis tersebut dilakukan agar dapat mencegah timbulnya permasalahan yang ada. Dimana pemetaan fungsi waktu ini memungkinkan pengguna untuk mengidentifikasi dan menghilangkan pemborosan waktu yang terjadi.

\section{TINJAUAN PUSTAKA}

Strategi proses atau strategi transformasi adalah sebuah pendekatan organisasi untuk mengubah sumber daya menjadi barang dan jasa. Tujuan strategi proses adalah menemukan suatu cara memproduksi barang dan jasa yang memenuhi persyaratan dari pelanggan dan spesifikasi produk yang ada dalam batasan biaya dan batasan manajerial lainnya. Proses yang dipilih akan berdampak jangka panjang terhadap efisiensi dan produksi, serta fleksibilitas, biaya, dan kualitas barang yang diproduksi.

Rangkuti (2000:44) menyatakan bahwa strategi yang diformulasikan dan diimplementasikan di unit-unit operasional seperti penjualan, distribusi, penyimpanan, promosi, persediaan, penggajian dan lain-lain. Keberhasilan manager pada jajaran ini akan menentukan kelancaran proses dan kesuksesan organisasi secara keseluruhan. Kelancaran kegiatan produksi dan operasi sangat ditentukan oleh kelancaran tersedianya bahan atau masukan yang dibutuhkan bagi produksi dan operasi tersebut. Kelancaran tersedianya bahan atau masukan bagi produksi dan operasi ditentukan oleh baik tidaknya pengadaan bahan serta rencana dan pengendalian persediaan yang dilakukan (Assauri, 2004;18-19)

Perencanaan proses berkenaan dengan perancangan dan implementasi sistem kerja yang akan memproduksi produk yang diinginkan dalam kuantitas yang diperlukan. Keputusankeputusan yang diambil dalam 
perencanaan proses memengaruhi keputusan-keputusan dalam bagianbagian operasi lain, seperti scheduling produksi, tingkat persediaan, desain pekerjaan, dan metode-metode pengawasan yang akan digunakan. (Handoko, 1996).

Dari berbagai pendapat para ahli yang telah dikemukakan di atas, dapat disimpulkan bahwa strategi proses merupakan suatu strategi yang digunakan oleh suatu perusahaan untuk merubah sumber daya menjadi barang dan jasa dengan memanfaatkan faktor-faktor yang tersedia seperti tenaga kerja, mesin, bahan baku, dan dana untuk kebutuhan manusia. Strategi proses yang diterapkan pada suatu perusahaan akan memengaruhi desain proses untuk memanfaatkan sarana pengolahan suatu produk Salah satu analisis desain proses yang dapat digunakan untuk meminimalisir pemborosan waktu pada suatu proses produksi adalah pemetaan fungsi waktu. Pemetaan fungsi waktu menggambarkan langkah-langkah proses yang akan dialami bahan baku mengenai urutan proses produksi.

Menurut Heizer dan Render (2009), pemetaan fungsi waktu dapat digunakan untuk membantu meminimalisir kompleksitas dari suatu proses produksi. Sebelum membuat diagram fungsi waktu, terlebih dahulu harus membuat diagram alir yang merupakan gambaran dari perpindahan bahan, produk, atau orang. Setelah membuat diagram alir, maka membuat diagram pemetaan fungsi waktu dengan menambahkan waktu pada sumbu horizontal.

Diagram pemetaan fungsi waktu, pada titik-titiknya meng-indikasikan aktivitas, sedangkan pada panahpanahnya mengindikasi-kan arah aliran dengan waktu pada sumbu horizontalnya. Jenis analisis ini memungkinkan pengguna untuk mengidentifikasi dan menghilangkan pemborosan dalam hal langkah tambahan, pengulangan, dan keterlambatan yang tidak perlu. Dalam pemetaan ini, dihitung pula berapa lama waktu yang diperlukan dalam proses dari bahan baku hingga menjadi produk jadi.

Diagram pemetaan fungsi waktu terdiri dari dua diagram. Pertama, pemetaan fungsi waktu dasar, merupakan proses dan waktu yang dilakukan dalam suatu produksi sebelum dilakukan penghematan waktu. Kedua, pemetaan fungsi waktu target, merupakan proses dan waktu yang dilakukan dalam suatu proses produksi setelah dilakukan kegiatan penghematan waktu. Diagram-diagram tersebut dapat digambarkan sebagai berikut: 


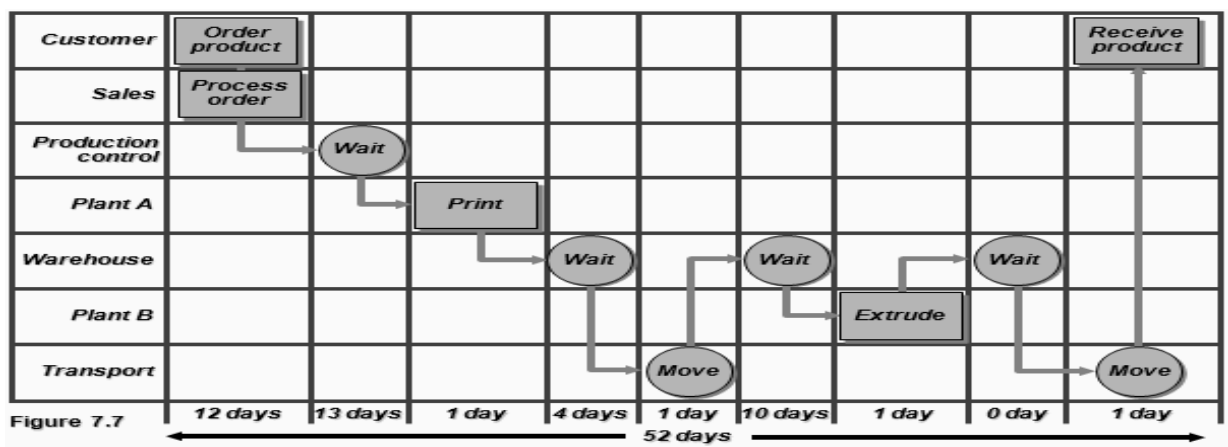

Gambar 1. Peta Fungsi Waktu Dasar (Baseline Time-Function Map)

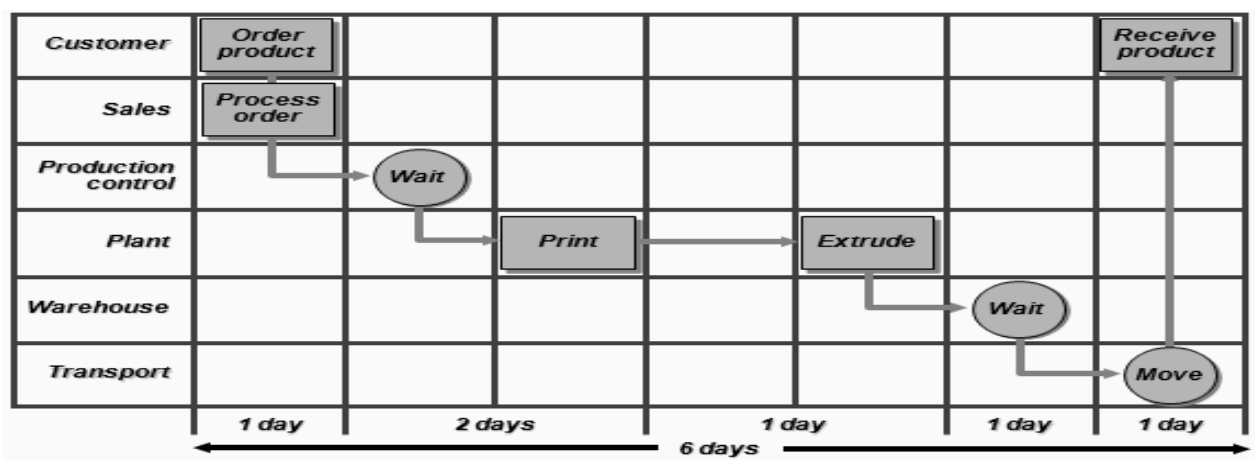

Gambar 2. Peta Fungsi Waktu Target (Target Time-Function Map)

Berdasarkan pemetaan fungsi waktu target, dapat diketahui penghematan proses maupun waktu yang dapat dilakukan dalam proses

\section{METODE PENELITIAN}

Penelitian ini dilakukan di Home industri (Cosh Motor) yang berlokasi di Jl. Hangtuah Gg. VIII/9 belakang masjid Galpungu Pasuruan. Adapun jenis penelitian yang digunakan adalah penelitian evaluatif. Penelitian evaluatif pada dasarnya merupakan bagian dari penelitian terapan namun tujuannya dapat dibedakan dari penelitian terapan. Penelitian ini dimaksudkan untuk mengukur keberhasilan suatu program, produk atau kegiatan tertentu (Danim, 2000). Penelitian ini diarahkan untuk menilai keberhasilan manfaat, kegunaan, sumbangan dan kelayakan suatu produksi suatu perusahaan. Dengan demikian proses produksi dapat berlangsung lebih efisien, efektif, dan optimal.

program kegiatan dari suatu unit/lembaga tertentu. Penelitian evaluatif dapat dirancang untuk menjawab pertanyaan, menguji, atau membuktikan hipotesis. Jadi yang dimaksud dengan penelitian evaluatif adalah penelitian yang bertujuan untuk mengumpulkan informasi tentang apa yang terjadi, yang merupakan kondisi nyata mengenai keterlaksanaan rencana yang memerlukan evaluasi.

Definisi operasi variabel pada dasarnya segala sesuatu yang berbentuk apa saja yang ditetapkan oleh peneliti untuk dipelajari sehingga diperoleh informasi tentang hal tersebut, kemudian ditarik 
kesimpulannya. (Sugiyono, 2007). Definisi operasi ini memberikan informasi yang diperlukan untuk mengukur variabel yang akan diteliti. Berikut ini disebutkan masing-masing variabel dan sekaligus beserta definisi operasionalnya.Merupakan tahapan waktu dalam memproses bahan mentah berupa logam menjadi barang jadi yaitu aksesoris motor, yang selama ini telah diterapkan oleh perusahaan dengan hitungan permenit. Dengan meng-hitung proses waktu awal sebelum dan setelah dianalisis. Segala sesuatu yang dipergunakan oleh perusahaan sebagai komponen produk yang akan diproduksi, terdiri dari bahan baku utama dan bahan baku pendukung. Bahan baku utama berupa logam. Bahan baku pendukung berupa cat, plastik, kertas label, dan lain-lain. Merupakan alat yang diperguna-kan untuk mendukung kegiatan operasional perusahaan dalam hal ini adalah produksi aksesoris motor. Dengan indikator berupa mesin mesin cetak, mesin bubut, serta mesin pewarnaan. Human (tenaga kerja) Para pekerja yang melakukan pekerjaan yang terlibat dalam kegiatan proses produksi. Dengan indikator, pekerja merupakan karyawan home industry cosh motor. Metode Instruksi kerja atau perintah kreja yang harus diikuti dalam proses produksi. Dengan indikator, setiap instruksi yang diberikan sesuai dengan tingkat kesulitan dan bahan baku yang dipergunakan.

Kegiatan proses produksi dalam usaha untuk menghasilkan atau mengubah bahan mentah menjadi suatu barang, dalam hal ini adalah pembuatan aksesoris motor. Dimulai dari mengolah bahan mentah berupa logam menjadi sebuah aksesoris motor.Merupakan tahapan waktu dalam hitungan menit, untuk memproses bahan mentah menjadi barang jadi yang telah dianalisis guna menghilangkan waktu-waktu yang tidak perlu dalam setiap prosesnya. Untuk mengetahui kegiatan yang dilakukan dan waktu yang diperlukan dalam melakukan proses produksi saat ini pada Home Industri "Cosh Motor" dapat dihitung menggunakan peta fungsi waktu dasar. Contoh gambaran peta fungsi waktu dasar adalah sebagai berikut:

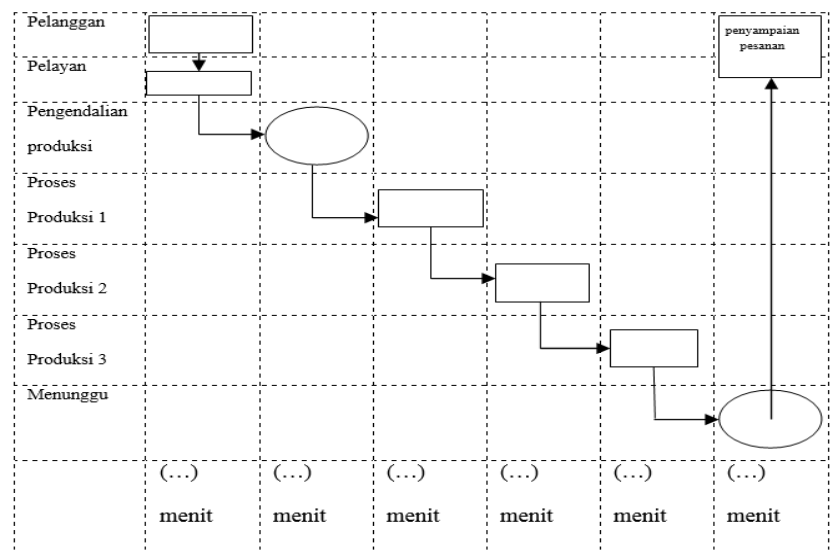

Gambar 3. Pemetaan Fungsi Waktu Dasar 
Pemetaan Fungsi Waktu Target utnuk mengetahui kegiatan yang dilakukan dan waktu yang diperlukan dalam melakukan proses produksi setelah dilakukan perbaikan, dapat dihitung menggunakan peta fungsi waktu target. Contoh gambaran peta fungsi waktu target adalah sebagai berikut:

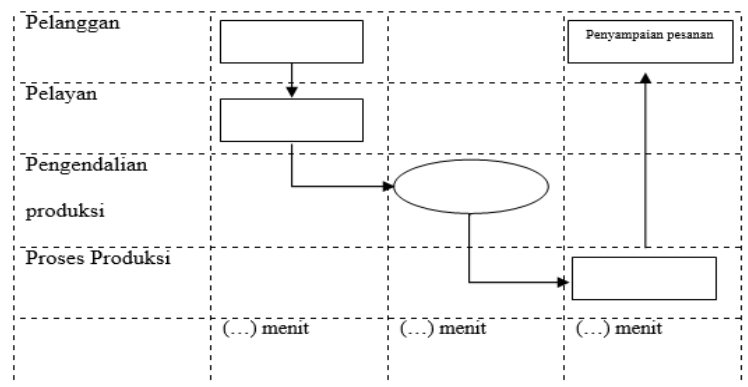

Gambar 4. Pemetaan Fungsi Waktu Garis Target

\section{HASIL PENELITIAN}

Daftar produk yang diproduksi ini adalah daftar produk-produk yang dipesan oleh 30 pelanggan produk yang dipesan dan diproduksi ada pada Tabel 2 berikut:

Tabel 2. Daftar Produk yang diproduksi

\begin{tabular}{|c|c|c|c|c|c|}
\hline No. & Nama Produk & Jumlah Pesanan & Satuan Pesanan & Isi & Total Isi \\
\hline 1. & Pangkon stang pendek & 25 & SET & 2 & 50 \\
\hline 2. & Tutup pentil dadu & 45 & PEPEL & 32 & 1440 \\
\hline 3. & Pangkon stang panjang & 30 & SET & 2 & 60 \\
\hline 4. & Braket Nium Jupiter 30 & 30 & PCS & 1 & 30 \\
\hline 5. & Pangkon skok kharisma tanggung & 20 & SET & 2 & 40 \\
\hline 6. & Baut Krucut EL Chrome & 30 & PEPEL & 48 & 1440 \\
\hline 7. & Pangkon Skok Shogun 125 Tanggung & 40 & SET & 2 & 80 \\
\hline 8. & Tutup Klep Supra & 30 & PCS & 1 & 30 \\
\hline 9. & Pangkon Skok Kharisma Pendek & 35 & SET & 2 & 70 \\
\hline 10. & Braket Nium Beat 30 & 30 & PCS & 1 & 30 \\
\hline 11. & Handel kanan vixion & 25 & PCS & 1 & 25 \\
\hline 12. & Pangkon skok kharisma panjang & 35 & SET & 2 & 70 \\
\hline 13. & Tutup pentil mutiara & 30 & PEPEL & 32 & 960 \\
\hline 14. & Peninggi skok U biru cops & 30 & SET & 2 & 60 \\
\hline 15. & Handel kiri poles & 25 & PCS & 1 & 25 \\
\hline 16. & Braket nium jupiter MX26 & 30 & PCS & 1 & 30 \\
\hline 17. & Peninggi vixion & 30 & SET & 2 & 60 \\
\hline 18. & Peninggi stang $283,5 \mathrm{~cm}$ & 35 & SET & 2 & 70 \\
\hline 19. & Baut plat EL Biru & 45 & PEPEL & 48 & 2160 \\
\hline 20. & Peninggi skok U New Pangkon & 35 & SET & 2 & 70 \\
\hline 21. & Peninggi stang $28 \mathrm{~mm}$ fatbar sedang & 25 & SET & 2 & 50 \\
\hline 22. & Peninggi stang cops & 35 & SET & 2 & 70 \\
\hline 23. & Tuutp pentil rocket & 35 & PEPEL & 25 & 875 \\
\hline 24 & Braket chrome supra 30 & 40 & PCS & 1 & 40 \\
\hline 25. & Braket chrome mio 30 & 35 & PCS & 1 & 35 \\
\hline 26. & Handelkanan shogun & 30 & PCS & 1 & 30 \\
\hline 27. & Baut plat golg & 30 & PEPEL & 48 & 1440 \\
\hline 28. & Braket crhome beast 26 & 30 & PCS & 1 & 30 \\
\hline 29. & Tutup klep yamaha & 35 & PCS & 1 & 35 \\
\hline 30 & Braket chrome mio soul 35 & 25 & PCS & 1 & 25 \\
\hline
\end{tabular}


Pemetaan fungsi waktu dasar untuk mengetahui kegiatan-kegiatan yang dilakukan dan waktu yang diperlukan dalam melakukan proses produksi saat ini pada Home Industry "Cosh Motor" dapat dihitung menggunakan peta fungsi waktu dasar.
Langkah-langkah proses untuk membuat diagram pemetaan fungsi waktu dasar adalah sebagai berikut: Pertama yang dilakukan adalah membuat diagram alir dengan divisidivisi pada sumbu vertikal dan waktu pada sumbu horizontal.

Tabel 3. Divisi pada sumbu vertikal

\begin{tabular}{cl}
\hline No. & \multicolumn{1}{c}{ Divisi } \\
\hline 1 & Pelanggan \\
2 & Pegawai \\
3 & Proses produksi 1 (peleburan) \\
4 & Proses produksi 2 (pencetakan) \\
5 & Proses produksi 3 (pembubutan) \\
6 & Proses produksi 4 (pewarnaan) \\
7 & Proses produksi 5 (pengemasan) \\
8 & Gudang \\
9 & Transportasi \\
\hline
\end{tabular}

Berdasarkan Tabel 3, maka dapat dilihat bahwa divisi-divisi pada sumbu vertikal untuk membuat pemetaan fungsi waktu ada sembilan divisi. Menyusun kegiatan-kegiatan dalam proses produksi mulai dari pelanggan memesan produk hingga produk sampai kepada pelanggan. Pada langkah ini dilakukan pengamatan dengan melihat langsung proses produksi dimulai dari pegawai mencatat pesanan pelanggan, proses produksi, hingga proses transportasi produk ke pelanggan.

Pelanggan yang diamati sejumlah 30 pelanggan dengan produk yang dipesan berbeda-beda produk pada tiap-tiap pelanggan, pelanggan yang dimaksud ini adalah bengkel-bengkel kecil maupun distributor yang ingin menjual kembali pada bengkelbengkel kecil dikota mereka. Kegiatan atau proses untuk pemetaan fungsi waktu dapat dilihat pada Tabel 4 .

Tabel 4. Kegiatan yang terjadi

\begin{tabular}{cl}
\hline No. & \multicolumn{1}{c}{ Kegiatan } \\
\hline 1 & Memesan produk \\
2 & Mencatat pesanan \\
3 & Prosesmenunggu produksi \\
4 & Proses peleburan \\
5 & Proses pencetakan \\
6 & Proses menunggu pembubutan \\
7 & Proses pembubutan \\
8 & Proses menunggu pewarnaan \\
9 & Proses pewarnaan \\
10 & Proses pengemasan \\
11 & Proses menunggu di gudang \\
12 & Proses transportasi barang ke pelanggan \\
13 & Penyampaian produk \\
\hline
\end{tabular}


Berdasarkan Tabel 4, maka dapat dilihat bahwa proses atau kegiatan dimulai dari pelanggan memesan produk hingga produk sampai ke tangan pelanggan terdapat tiga belas proses atau kegiatan.

Menghitung waktu dari masing- masing kegiatan dalam proses produksi mulai dari pelanggan hingga pesanan produk sampai kepada pelanggan.

Pada langkah ini seluruh kegiatan dihitung waktunya, terutama pada proses produksi.

Tabel 5. Waktu proses

\begin{tabular}{clcc}
\hline No. & & Tahapan Proses & Waktu \\
\hline 1. & Pelayanan pelanggan & Memesan produk & 1 hari \\
& & Mencatat pesanan & 2 hari \\
2. & Pengendalian proses & Menunggu & 30 menit \\
3. & Produksi & Peleburan & 30 menit \\
& & Pencetakan & 15 menit \\
& & Menunggu & 15 menit \\
& & Pembubutan & 15 menit \\
& & Menunggu & 30 menit \\
& & Pewarnaan & 75 menit \\
4. & Gudang & Pengemasan & 10 menit \\
5. & Transportasi & Penyimpanan & 1 hari \\
\end{tabular}

Berdasarkan tabel 5 waktu proses, maka dapat dilihat bahwa proses operasional mulai dari pelanggan memesan produk hingga produk sampai ke tangan pelanggan memakan waktu selama 6 hari 3.4 jam.

Membuat diagram pemetaan fungsi waktu dasar. Langkah yang terakhir adalah mendesain atau membuat diagram pemetaan fungsi waktu dasar. Salah satu contoh gambar diagram pemetaan fungsi waktu dasar dapat dilihat pada gambar 5. Pada gambar 5, diketahui terjadi pemborosan waktu dalam proses produksi. Hal ini dilihat dari proses pengendalian produksi serta waktu yang diperlukan untuk melakukan proses produksi melebihi waktu standar yang ditetapkan. Waktu standar adalah 1 hari proses pemesanan, 1 hari proses produksi dengan rincian proses peleburan 30 menit, proses pencetakan 30 menit, proses pembubutan 15 menit, pewarnaan 60 menit, dan pengemasan 10 menit. $1 / 2$ hari produk masuk gudang, $1 / 2$ hari transportasi produk ke pelanggan.

Pada gambar 5 dapat dibuat analisa permasalahan pelanggan. Pada analisa diketahui bahwa dari 30 pelanggan terdapat permasalahan, yaitu pemborosan waktu dalam proses pelayanan dan produksi. Hal ini dikarenakan proses produksi suatu produk membutuhkan waktu yang cukup lama serta kurangnya mesin untuk proses produksi. Mulai dari pencatatan pesanan produk dari pelanggan, proses produksi tahap peleburan ke tahap pencetakan, setelah proses pencetakan masih menunggu ke tahap pembubutan, menunggu kembali ke tahap pewarnaan, dari pewarnaan ke tahap pengemasan produk, setelah produk dikemas, produk masuk kedalam gudang, lalu 
tahap terakhir yaitu transportasi produk ke pelanggan dan simpulkan bahwa permasalahan proses produksi dapat dilihat pada Tabel 6.

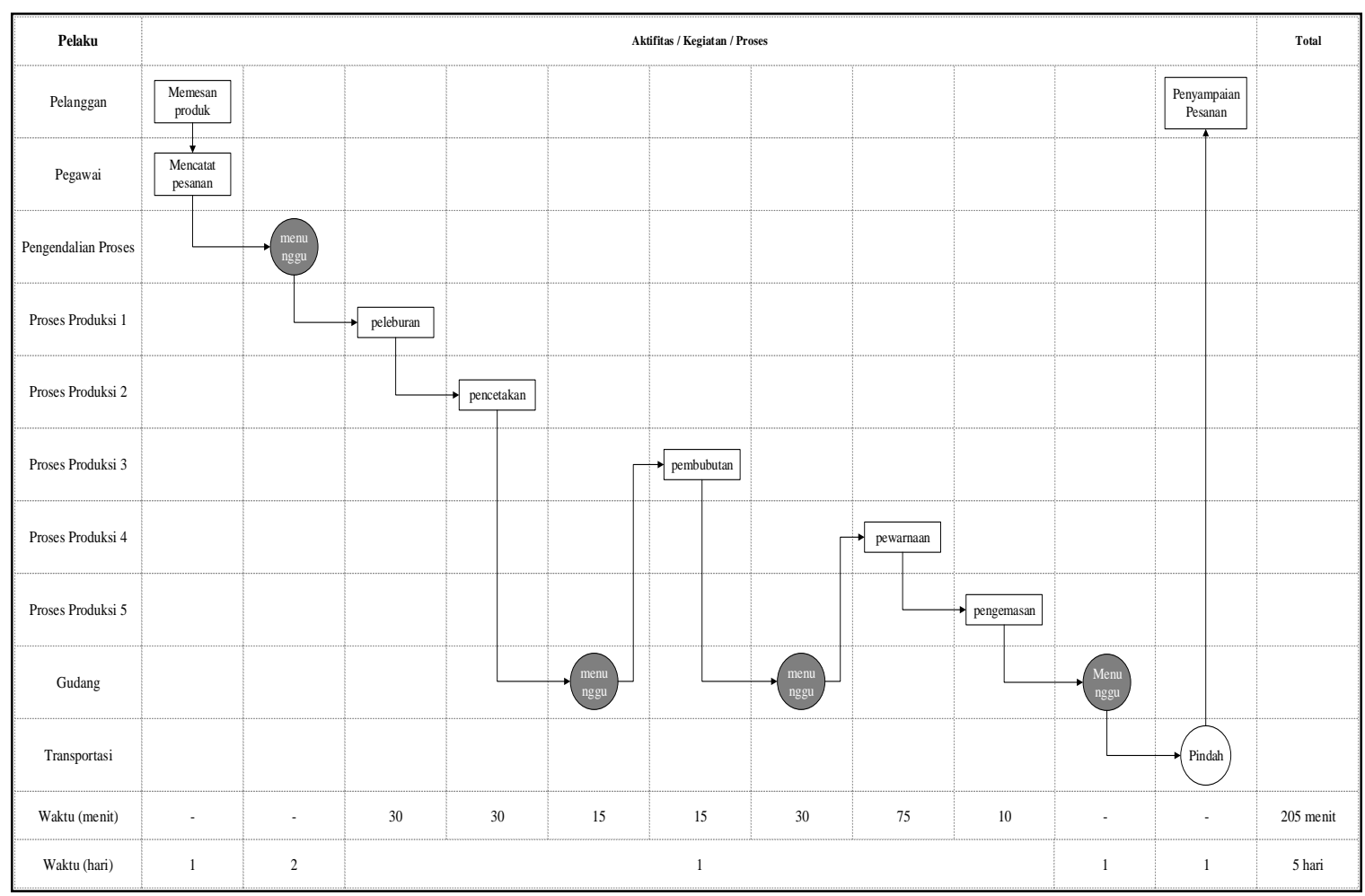

Gambar 5. Pemetaan

Tabel 6. Permasalahan Proses Produksi

\begin{tabular}{cl}
\hline No. & \multicolumn{1}{c}{ Permasalahan } \\
\hline 1 & Pengendalian proses \\
2 & Menunggu pembubutan \\
3 & Menunggu pewarnaan \\
4 & Gudang \\
\hline
\end{tabular}

Permasalahan - permasalahan kegiatan produksi dapat diketahui dengan mengamati proses produksi serta wawancara kepada pegawai yang melakukan kegiatan produksi. Permasalahan yang terjadi pada 30 pelanggan disebabkan dua faktor yaitu kurang telitinya manusia serta kurangnya mesin/peralatan dalam proses produksi.

Hal ini dapat menyebabkan banyaknya waktu menunggu dari tahap 1 ke tahap selanjutnya. Seperti pada tahap pencetakan ke tahap pembubutan, tahap pembubutan ke tahap pewarnaan. Solusi-solusi penyelesaian permasalahan dapat dilihat pada tabel 7 sebagai berikut: 
Tabel 7. Solusi Permasalahan

\begin{tabular}{|c|c|c|}
\hline Solusi & Keuntungan & Kerugian \\
\hline Menambah tungku peleburan & Mempercepat proses produksi & $\begin{array}{c}\text { Mengeluarkan biaya } \\
\text { penambahan mesin }\end{array}$ \\
\hline Menambah mesin pembubutan & Mempercepat proses pembubutan & $\begin{array}{l}\text { Mengeluarkan biaya } \\
\text { penambahan mesin }\end{array}$ \\
\hline Menambah mesin pewarnaan & Mempercepat proses pewarnaan & $\begin{array}{l}\text { Mengeluarkan biaya } \\
\text { penambahan mesin }\end{array}$ \\
\hline $\begin{array}{l}\text { Mengerjakan proses produksi } \\
\text { sekaligus }\end{array}$ & $\begin{array}{l}\text { Mengurangi terjadinya penumpukan } \\
\text { produk }\end{array}$ & - \\
\hline
\end{tabular}

Pemetaan Fungsi Waktu Target. Untuk mengetahui kegiatan-kegiatan yang dilakukan dan waktu yang diperlukan dalam melakukan proses produksi setelah dilakukan perbaikan, dapat dihitung mengguna-kan peta fungsi waktu target.

Diagram pemetaan fungsi waktu target sama dengan diagram pemetaan fungsi waktu dasar, namun pada langkah ini dibandingkan kedua peta fungsi waktu tersebut. Pada peta fungsi waktu target dilakukan pengamatan kepada pelanggan 30 pelanggan serta perbandingan yang bertujuan untuk mengetahui bahwa hasil pemetaan fungsi waktu target lebih efisien dan efektif.

Perbandingan hasil analisa pemetaan fungsi waktu dasar dengan hasil pemetaan fungsi waktu target dapat dilihat pada tabel 8 .

Tabel 8. Perbandingan hasil analisa pemetaan fungsi waktu dasar dengan pemetaan fungsi waktu target.

\begin{tabular}{ll}
\hline Pemetaan fungsi waktu dasar & Pemetaan fungsi waktu target \\
\hline 1. Pencatatan pesanan & 1. Pencatatan pesanan \\
2. Pengendalian proses & 2. Produksi \\
3. Produksi: & a. Peleburan \\
a. Peleburan & b. Pencetakan \\
b. Pencetakan & c. Pembubutan \\
c. Menunggu & d. Pewarnaan \\
d. Pembubutan & e. Pengemasan \\
e. Menunggu & 3. Transportasi produk ke pelanggan \\
f. Pewarnaan & \\
g. Pengemasan & \\
4. Gudang & \\
5. Transportasi produk ke pelanggan & \\
\hline
\end{tabular}


Berdasarkan pada Tabel 8, maka perbandingan pemetaan fungsi waktu dasar dengan pemetaan fungsi waktu target dapat diketahui bahwa pada fungsi waktu dasar masih banyaknya proses yang tidak diperlukan. Dengan demikian waktu yang diperlukan untuk proses produksi sudah efektif dan efisien. Gambar diagram pemetaan fungsi waktu target secara umum dapat digambarkan pada gambar 6 .

Pada Gambar 6 kegiatan yang tidak diperlukan proses pemetaan fungsi waktu dasar telah dihapus pada pemetaan fungsi waktu target. Selain itu waktu yang diperlukan untuk melakukan proses produksi tidak melebihi dari waktu standar yang ditetapkan sehingga waktu mulai dari pemesanan produk oleh pelanggan hingga produk sampai ke tangan pelanggan tidak menunggu waktu lama.

Permasalahan Proses Produksi, Proses produksi adalah suatu cara, metode ataupun teknik menambah kegunaan suatu barang dan jasa dengan menggunakan faktor produksi yang ada. Berdasarkan hasil analisis data yang telah dilakukan baik dengan cara mengamati proses produksi serta wawancara, membuktikan bahwa proses produksi yang dilakukan masih terdapat adanya pemborosan waktu, hal ini dapat dilihat pada Gambar 5 diagram pemetaan fungsi waktu dasar.

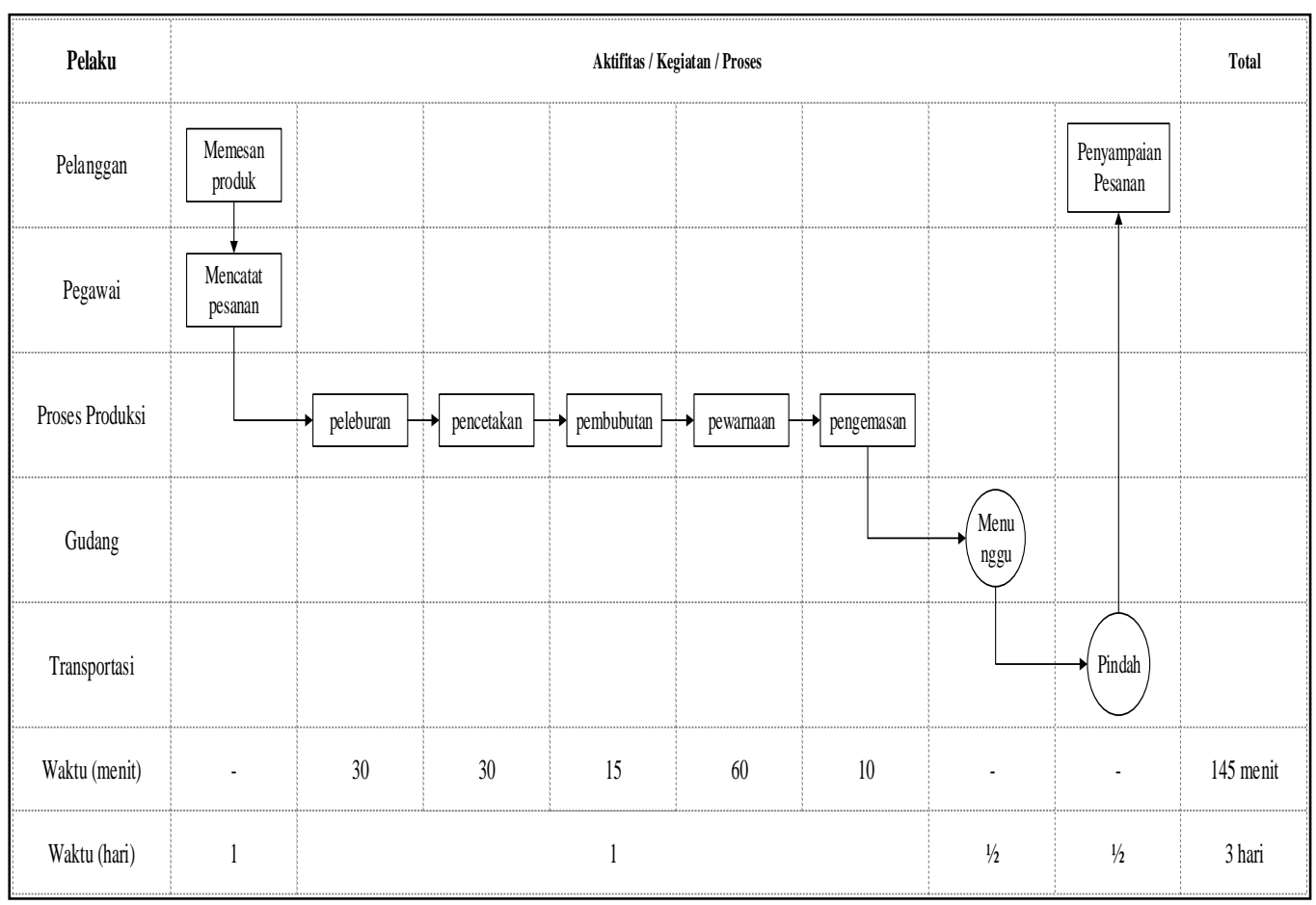

Gambar 6. Pemetaan Fungsi Waktu Target 
Tabel 9. Analisa hasil pemetaan fungsi waktu dasar 30 pelanggan

\begin{tabular}{|c|c|c|c|c|c|c|c|c|c|c|c|c|c|}
\hline \multirow[b]{2}{*}{$\begin{array}{c}\text { Pesanan } \\
\text { Pelanggan }\end{array}$} & \multicolumn{12}{|c|}{ Permasalahan } & \multirow[b]{2}{*}{ 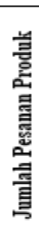 } \\
\hline & $\begin{array}{l}\text { 弟 } \\
\text { 言 } \\
\text { 总 } \\
\text { 总 }\end{array}$ & 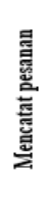 & 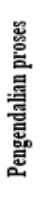 & 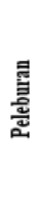 & 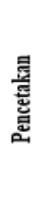 & 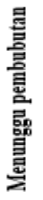 & $\begin{array}{l}\text { 吾 } \\
\text { 言 } \\
\text { 㐭 } \\
\text { م. }\end{array}$ & 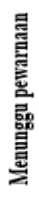 & $\begin{array}{l}\text { है } \\
\text { 宸 } \\
\text { 竎 }\end{array}$ & 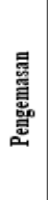 & 哭 & 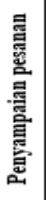 & \\
\hline Pangkon Stang Pendek & & & $\sqrt{2}$ & & & $\sqrt{2}$ & & $\sqrt{ }$ & & & $\sqrt{2}$ & & 25 \\
\hline Tutup Pentil Dadu & & & $\sqrt{3}$ & & & $\sqrt{2}$ & & $\sqrt{3}$ & & & $\sqrt{1}$ & & 45 \\
\hline Pangkon Stang Panjang & & & $\sqrt{2}$ & & & $\sqrt{2}$ & & $\sqrt{1}$ & & & $\sqrt{2}$ & & 30 \\
\hline Braket Nium Jupiter 30 & & & $\sqrt{2}$ & & & $\sqrt{2}$ & & $\sqrt[3]{ }$ & & & $\sqrt[3]{ }$ & & 30 \\
\hline Pangkon Skok Karisma Tanggung & & & $\sqrt{3}$ & & & $\sqrt{2}$ & & $\sqrt{3}$ & & & $\sqrt{2}$ & & 20 \\
\hline Baut Krucut EL Chrome & & & $\sqrt{ }$ & & & $\sqrt{ }$ & & $\sqrt{ }$ & & & $\sqrt{2}$ & & 30 \\
\hline Pangkon Skok Shogun 125 Tanggung & & & $\sqrt{2}$ & & & $\sqrt{2}$ & & $\sqrt{ }$ & & & $\sqrt{2}$ & & 40 \\
\hline Tutup Klep Supra & & & $\sqrt{2}$ & & & $\sqrt{2}$ & & $\sqrt{1}$ & & & $\sqrt{2}$ & & 30 \\
\hline Pangkon Skok Karisma Pendek & & & $\sqrt{2}$ & & & $\sqrt{2}$ & & $\sqrt{2}$ & & & $\sqrt{2}$ & & 35 \\
\hline Braket Nium Beat 30 & & & $\sqrt{2}$ & & & $\sqrt{2}$ & & $\sqrt{3}$ & & & $\sqrt{2}$ & & 30 \\
\hline Handel Kanan Vixion & & & $\sqrt{3}$ & & & $\sqrt{2}$ & & $\sqrt{2}$ & & & $\sqrt{2}$ & & 25 \\
\hline Pangkon Skok Karisma Panjang & & & $\sqrt{ }$ & & & $\sqrt{2}$ & & $\sqrt{2}$ & & & $\sqrt{2}$ & & 35 \\
\hline Tutup Pentil Mutiara & & & $\sqrt{3}$ & & & $\sqrt{2}$ & & $\sqrt{ }$ & & & $\sqrt{2}$ & & 30 \\
\hline Peninggi Skok U Biru Cops & & & $\sqrt{3}$ & & & $\sqrt{2}$ & & $\sqrt{2}$ & & & $\sqrt{2}$ & & 30 \\
\hline Handel Kiri Poles & & & $\sqrt{ }$ & & & $\sqrt{2}$ & & $\sqrt{2}$ & & & $\sqrt{2}$ & & 25 \\
\hline Brakket Nium Jupiter MX 26 & & & $\sqrt{2}$ & & & $\sqrt{2}$ & & $\sqrt{2}$ & & & $\sqrt{2}$ & & 30 \\
\hline Peninggi Vixion & & & $\sqrt{2}$ & & & $\sqrt{2}$ & & $\sqrt{2}$ & & & $\sqrt{2}$ & & 30 \\
\hline Peninggi Stang $283.5 \mathrm{~cm}$ & & & $\sqrt{ }$ & & & $\sqrt{ }$ & & $\sqrt{ }$ & & & $\sqrt{2}$ & & 35 \\
\hline Baut Plat EL Biru & & & $\sqrt{ }$ & & & $\sqrt{ }$ & & $\sqrt{ }$ & & & $\sqrt{ }$ & & 45 \\
\hline Peninggi Skok U New Pangkon & & & $\sqrt{ }$ & & & $\sqrt{ }$ & & $\sqrt{ }$ & & & $\sqrt{ }$ & & 35 \\
\hline Peninggi Stang $28 \mathrm{~mm}$ Fatbar Sedang & & & $\sqrt{2}$ & & & $\sqrt{ }$ & & $\sqrt{2}$ & & & $\sqrt{2}$ & & 25 \\
\hline Peninggi Stang Cops & & & $\sqrt{2}$ & & & $\sqrt{3}$ & & $\sqrt{2}$ & & & $\sqrt{1}$ & & 35 \\
\hline Tutup Pentil Rocket & & & $\sqrt{ }$ & & & $\sqrt{2}$ & & $\sqrt{2}$ & & & $\sqrt{2}$ & & 35 \\
\hline Braket Chrome Supra 30 & & & $\sqrt{ }$ & & & $\sqrt{ }$ & & $\sqrt{ }$ & & & $\sqrt{ }$ & & 40 \\
\hline Braket Chrome Mio 30 & & & $\sqrt{ }$ & & & $\sqrt{3}$ & & $\sqrt{ }$ & & & $\sqrt{3}$ & & 35 \\
\hline Handel Kanan Shogun & & & $\sqrt{3}$ & & & $\sqrt{3}$ & & $\sqrt{3}$ & & & $\sqrt{3}$ & & 30 \\
\hline Baut Plat Golg & & & $\sqrt{ }$ & & & $\sqrt{ }$ & & $\sqrt{ }$ & & & $\sqrt{ }$ & & 30 \\
\hline Braket Chrome Beat 26 & & & $\sqrt{2}$ & & & $\sqrt{ }$ & & $\sqrt{1}$ & & & $\sqrt{ }$ & & 30 \\
\hline Tutup Klep Yamaha & & & $\sqrt{3}$ & & & $\sqrt{2}$ & & $\sqrt{1}$ & & & $\sqrt{1}$ & & 35 \\
\hline Braket Chrome Mio Soul 35 & & & $\sqrt{ }$ & & & $\sqrt{ }$ & & $\sqrt{ }$ & & & $\sqrt{ }$ & & 25 \\
\hline
\end{tabular}

Pada proses ini, yang dapat menyebabkan pemborosan waktu adalah mesih bubut hanya satu sehingga agar logam yang telah dicetak dan siap untuk dibubut mengalami penumpukan dan dapat mengalami pemborosan waktu. Produk yang siap untuk diwarnai juga terdapat pemborosan waktu, hal ini disebabkan peralatan untuk pewarnaan hanya sedikit sedangkan produk yang akan diwarna banyak, faktor lain yang menyebabkan pemborosan waktu adalah kurang telitinya pegawai yang melakukan pewarnaan produk sehingga produk yang telah diwarnai mengalami tidak sempurna atau cacat pada pewarnaannya.

Oleh karena itu jika produk mengalami cacat pada pewarnaannya, maka produk tersebut harus dilakukan pewarnaan ulang, hal ini dapat mengalami pemborosan waktu. Banyaknya pesanan produk dari pelanggan, seperti satu pelanggan memesan beberapa produk, sehingga daftar pesanan produk dari pelanggan agar siap untuk didistribusikan mengalami proses menunggu beberapa produk yang telah diproduksi. Hal ini dapat menyebabkan penumpukan produk dan mengalami pemborosan waktu.

Maka, dilihat dari keempat permasalahan proses produksi sebelumnya, yang menyebabkan pemborosan waktu adalah proses menunggu selesainya proses produksi sebelumnya. Proses menunggu selesainya proses produksi sebelumnya ini terdapat dua faktor utama yaitu: Kegiatan produksi yang dilakukan oleh perusahaan tidak akan berjalan dengan efektif jika mesin yang digunakan perusahaan kurang. Hal ini dapat menyebabkan tidak dapat menyelesaikan produksi barang dengan tepat waktu, sedangkan permintaan produk dari pelanggan begitu banyak.

Dari tahap permasalahan yang ada, dapat diketahui bahwa mesin/peralatan yang kurang yaitu tungku peleburan, mesin pembubutan, dan pewarnaan. Faktor pekerja atau karyawan yang kurang teliti atau kurang focus dalam mengerjakan setiap produk membuat produk kadangkala 
produk yang dihasilkan cacat atau prosesnya lama. Hal ini dapat menyebabkan pemborosan waktu dalam proses produksinya.

Permasalahan-permasalahan pada proses produksi seringkali terjadi. Oleh karena itu dari setiap permasalahan diharapkan terdapat solusi penyelesaian dari permasalahan yang ada. Solusi-solusi dalam penyelesaian permasalahan proses produksi yang ada adalah sebagai berikut:

Agar tidak terjadi proses menunggu yang lama pada proses peleburan logam. Solusi dari permasalahan ini adalah dengan cara menambah tungku peleburan, keuntungan yang didapat dari solusi ini mempercepat proses produksi serta mengurangi pemborosan waktu. Namun, solusi ini memiliki kerugian yaitu membebankan perusahaan dengan mengeluarkan biaya ekstra dalam penambahan mesin/peralatan ini.

Agar tidak terjadinya proses menunggu pembubutan yang lama, solusinya adalah dengan menambah mesin pembubutan, dengan ini mendapatkan keuntungan yaitu mempercepat proses pembubutan dan mengurangi pemborosan waktu, namun dengan penambahan mesin ini, perusahaan mengalami kerugian yaitu mengeluarkan biaya untuk penambahan mesin ini.

Agar tidak terjadinya penumpukan produk dalam proses pewarnaan produk. Solusinya adalah dengan cara menambah mesin/peralatan untuk mewarnai produk, hal ini dapat mengurangi pemborosan waktu serta mempercepat proses produksi. Namun hal ini juga mengharuskan perusahaan mengeluarkan biaya ekstra dalam penambahan mesin/peralatan tersebut.

Agar tidak terjadinya penumpukan produk yang lama digudang dan produk cepat sampai di tangan pelanggan. solusinya adalah dengan cara mengerjakan proses produksi sekaligus dengan produk yang sejenis dari pesanan pelanggan yang lainnya. Solusi ini dapat mengurangi terjadinya penumpukan produk di gudang.

\section{SIMPULAN}

Berdasarkan hasil analisis permasalahan dan pembahasan pada bab sebelumnya yang terjadi pada proses produksi perusahaan home industry "cosh motor", maka dapat diambil kesimpulan bahwa dengan adanya desain diagram pemetaan fungsi waktu produksi serta mengimplementasikan solusi dari permasalahan yang ada, maka proses produksi telah mengalami peningkatan serta operasional perusahaan dapat berjalan secara efektif dan efisien.

\section{DAFTAR PUSTAKA}

Assauri, Sofjan. 1993. Manajemen Produksi. Edisi Ketiga. Lembaga Penerbit Fakultas Ekonomi Universitas Indonesia. Jakarta.

Assauri, Sofjan. 1999. Manajemen Produksi dan Operasi. Edisi Empat. Lembaga Penerbit Fakultas Ekonomi Universitas Indonesia, Jakarta.

Assauri, Sofjan. 2004. Manajemen Produksi dan Operasi Edisi Revisi 2004. Lembaga Penerbit FE-UI. Jakarta.

Freddy Rangkuti. 2000. Manajemen Persediaan, Cetakan keenam. Penerbit PT. Raja Grafindo Persada. Jakarta.

Handoko, T. Hani. 1996. Manajemen Personalia dan Sumber Daya Manusia. Penerbit BPFE. Yogyakarta.

Handoko, T., Hani. 1998. Dasar-dasar Manajemen Produksi dan Operasi. Penerbit BPFE, Yogyakarta

Heizer, Jay. \& Barry. Render. 2009. Manajemen Operasi, Edisi Sembilan. Salemba Empat. Jakarta 